\title{
TRACER STUDY PROGRAM STUDI S1 (STRATA-1) AKUNTANSI FAKULTAS EKONOMI DAN BISNIS UNIVERSITAS MATARAM TAHUN 2020
}

\author{
Adhitya Bayu Suryantara \\ Universitas Mataram \\ adhityabayus@unram.ac.id \\ Wirawan Suhaedi \\ Universitas Mataram \\ wirawan.suhaedi@gmail.com \\ Baiq Anggun Hilendri Lestari \\ Universitas Mataram \\ hilendria@gmail.com \\ $\begin{array}{rlr}\text { Disubmit } & : & 6 \text { Desember } 2021 \\ \text { Direview } & : & 14 \text { Desember } 2021 \\ \text { Diterima } & : & 18 \text { Desember } 2021\end{array}$
}

\begin{abstract}
Tracer study is useful for monitoring graduates and knowing the relevance of the competencies of graduates of the Accounting Department with the needs of stakeholders. There are three objectives of this research: 1) the evaluation of stakeholders on the performance of alumni; 2) The period for alumni to get their first job; 3) The relevance of the curriculum to the needs of stakeholders. According to stakeholders, the performance of the Accounting alumni is very good. The period for alumni to get their first job is 4 months. The relevance between the curriculum and the needs of stakeholders is quite appropriate.
\end{abstract}

Keywords : Tracer Study; Competencies; Performanace of Alumni

\begin{abstract}
Abstrak
Tracer study berguna untuk memantau lulusan dan mengetahui relevansi kompetensi lulusan Program Studi/Jurusan S1 Akuntansi dengan kebutuhan stakeholder. Terdapat tiga tujuan utama dari penelitian ini yaitu untuk mengetahui:1) penilaian stakeholders terhadap kinerja alumni; 2)Lama masa tunggu alumni sampai mendapatkan pekerjaan pertamanya; 3) Relevansi antara kurikulum dengan kebutuhan stakeholders. Tujuan tersebut akan dicapai dengan cara melakukan penelusuran (Tracer) pada Stakeholder yang ada di Kota Mataram. Kinerja alumni Prodi S1 akuntansi menurut stakeholders adalah sangat baik. Masa tunggu alumni sampai mendapatkan pekerjaan pertamanya adalah 4 bulan. Relevansi antara kurikulum dengan kebutuhan stakeholder sudah cukup sesuai, yang bisa dilihat dengan layaknya lulusan Program Studi S1 Akuntansi untuk bekerja pada berbagai organisasi, baik swasta maupun pemerintahan. Kata Kunci : Tracer Study ; Kompetensi ; Kualitas Lulusan
\end{abstract}

\section{PENDAHULUAN}

Lulusan yang sesuai kebutuhan pengguna (stakeholders) merupakan tuntutan yang harus dipenuhi oleh program studi/jurusan. Sejalan dengan hal itu, program studi (jurusan) harus 
melakukan perbaikan kualitas proses akademik secara berkesinambungan. Salah satu upaya memperbaiki kualitas adalah dengan melakukan pengembangan kurikulum berbasis kompetensi berdasarkan kebutuhan pengguna. Hal ini sesuai dengan amanat Direktorat Jenderal Dikti yang tertuang dalam Buku Panduan Pengembangan Kurikulum Berbasis Kompetensi Pendidikan Tinggi (2008) dan diperkuat dengan pasal 6 ayat (2) dan Pasal 97 Peraturan Pemerintah No.17 Tahun 2010 tentang pengelolaan dan penyelenggaraan pendidikan.

Menurut Mukhtaruddin dan Andriani (1999) yang dikutip oleh Cahyaningtyas (2007), landasan yang paling mendasar dalam pembentukan seorang profesional yang berkualitas, mampu bersaing dan memiliki keunggulan kompetitif dibidang akuntansi, bisa dicapai melalui pendidikan tinggi akuntansi yang mampu berintegrasi dengan perubahan-perubahan yang terjadi. Lebih lanjut, hasil kajian yang dilakukan oleh IBE-UNESCO pada tahun 1998 yang tercantum dalam panduan pengembangan dan penyusunan Kurikulum Pendidikan Tinggi (KPT) Pendekatan Kurikulum Berbasis Kompetensi (KBK) dan Pendidikan Berbasis Capaian (PBC) (Dikti, 2012) menyatakan bahwa tuntutan kemampuan tenaga kerja terdidik didasarkan pada 4 (empat) pilar pendidikan yaitu (1) belajar untuk tahu (learning to know), (2) belajar untuk berbuat (learning to do) perubahan dari keahlian ke kompetensi, dematerialisasi pekerjaan dan naiknya sektor layanan (the rise of service sector), serta bekerja di bidang ekonomi informal, (3) belajar untuk hidup bersama (learning to live together), belajar untuk hidup dengan orang lain (learning to live with others) menemukan orang lain dan bekerja untuk tujuan bersama (discovering others and working toward common objectives), dan (4) belajar untuk menjadi (learning to be).

Selain empat pilar tersebut tuntutan atas kemampuan tenaga kerja terdidik sangat terkait dengan perubahan pada tatanan global. Pengembangan Sumber Daya Manusia (SDM) yang bermutu melalui penyelenggaraan pendidikan yang berkualitas diharapkan mampu meningkatkan daya saing bangsa di level nasional maupun internasional. Daya saing dapat ditingkatkan melalui peningkatan kualitas dan relevansi lulusan program studi. Hal ini menuntut penyelenggaraan pendidikan bertanggung jawab dengan memfasilitasi anak didik dengan ilmu pengetahuan, keterampilan serta nilai dan sikap untuk berkompetisi secara fair di dunia kerja. (Cahyaningtyas, 2007). Perpres No 12 tahun 2012 menyatakan bahwa, lulusan pendidikan tinggi harus memiliki kualifikasi yang levelnya sesuai dengan strata dan jenis pendidikannya. Hal yang sama dijelaskan juga dalam panduan pengembangan dan penyusunan pendidikan tinggi oleh Dikti (2012) bahwa kurikulum pencapaian akhir dari penguasaan kompetensi dalam pelatihan dan dunia kerja adalah untuk dapat bekerja sesuai dengan kebutuhan pekerjaan.

Penguasaan kompetensi lulusan yang sesuai dengan kebutuhan pekerjaan maupun stakeholders dapat diketahui dari tracer study. Tracer study berfungsi menyediakan informasi mengenai hubungan antara pendidikan tinggi dan dunia kerja profesional. Dengan demikian tracer study merupakan alat untuk menilai relevansi kurikulum pendidikan tinggi dengan kebutuhan stakeholders. Dilain pihak, tracer study memberikan informasi mengenai situasi transisi dan dinamika kerja dan sebagai salah satu persyaratan akreditasi.

Program Studi S1 Akuntansi Fakultas Ekonomi dan Bisnis Universitas Mataram telah meluluskan ribuan mahasiswa sejak berdirinya pada tahun 1996, namuntracer studyjarang pernah dilakukan selama ini, sehingga Program Studi S1/ Jurusan Akuntansi Fakultas Ekonomi dan Bisnis Universitas Mataram memandang perlu dilakukannyatracer study secara berkala (setiap tahun). Tracer study bergunauntuk memantau lulusan dan mengetahui relevansi kompetensi lulusan Program Studi S1/ Jurusan Akuntansi dengan kebutuhan stakeholder. 


\section{METODE PENELITIAN}

Jenis penelitian ini adalah penelitian deskriptif. Penelitian ini memberikan gambaran mengenai lulusan dan kompetensi lulusan Program Studi / Jurusan S1Akuntansi Fakultas Ekonomi dan Bisnis Universitas Mataram yang dibutuhkan oleh stakeholder.

Populasi dalam penelitian ini adalah semua alumni lulusan Program Studi /Jurusan S1 Akuntansi Fakultas Ekonomi dan Bisnis Universitas Mataram. Sampel penelitian adalah sampel populasi yaitu semua lulusan Program Studi / Jurusan S1 Akuntansi Fakultas Ekonomi dan Bisnis Universitas Mataram.

Pengumpulan data dilakukan dengan personally administrated questionnaires. Metode ini dilakukan melalui penyebaran kuesioner berupa daftar pertanyaan (kuesioner) kepada responden dengan pertanyaan terkait (angket terstruktur). Data penelitian ini bersumber dari data primer, yaitu data yang bersumber dari data kuesioner.

\section{Variabel Penelitian}

Variabel-variabel yang digunakan dalam penelitian ini adalah:

1. Indeks Prestasi Komulatif merupakan ukuran keberhasilan mahasiswa yang dihitung mulai masa awal studi sampai semester terakhir yang telah diikuti yang dihitung dengan mengalikan nilai kredit dengan nilai bobot seluruh mata kuliah dibagi dengan jumlah sks mata kuliah yang diambil dalam kurun waktu tertentu

2. Masa Studimerupakan masa yang diperlukan oleh mahasiswa untuk menyelesaikan studi (kuliah). Masa studi dihitung sejak terdaftar menjadi mahasiswa sampai dengan ujian akhir (skripsi dan komprehensif)

3. Lama Waktu Tunggu Memperoleh Pekerjaan Pertama merupakan Waktu tunggu kerja (sejak wisuda sampai masuk kerja) lulusan

4. Besaran Gaji Pertama adalah besarnya gaji yang diterima pertama kali kerja oleh lulusan

5. Jumlah peminat program studi akuntansi merupakan jumlah calon mahasiswa yang mendaftar di Program Studi S1Akuntansi Fakultas Ekonomi dan Bisnis Universitas Mataramsetiap penerimaan mahasiswa baru

6. Jumlah Pengguna lulusan adalah jumlah instansi (institusi) yang menggunakan lulusan Program Studi / Jurusan S1 Akuntansi Fakultas Ekonomi dan Bisnis Universitas Mataramsebagai pegawai (karyawan)

Prosedur dan analisis data dapat dilakukan dengan langkah-langkah sebagai berikut:

1. Data yang terkumpul selanjutnya ditabulasi dan dianalisis secara statistik deskriptif

2. Data yang dianalisis adalah data yang tidak null, walaupun beberapa analisis masih mengikutsertakan data seperti ini. Untuk saat ini belum dilakukan cross analysis untuk melihat keterkaitan antar data.

3. Hasil analisis dituangkan dalam bentuk laporan yang memuat informasi statistik dan rekomendasi.

\section{HASIL DAN PEMBAHASAN}

Responden pada tracer study kali ini adalah semua alumni dan pengguna Program Studi S1 Akuntansi Fakultas Ekonomi dan Bisnis Universitas Mataram dari Tahun 2017 sampai dengan pertengahan Tahun 2020. Namun dari semua responden, hanya 184 orang Alumni dan 98 penguna yang mengisi kuesioner yang disebarkan dengan periode wisuda 2017 - 2020, 
sehingga didapatkan 184 data alumni dan 98 data pengguna yang dapat digunakan sebagai dasar untuk menganalisis.

Berikut ini adalah deskripsi responden berdasarkan jenis kelamin:

Tabel 4.1. Deskripsi Responden Alumni

\begin{tabular}{ccc}
\hline Tahun & \multicolumn{2}{c}{ Jenis Kelamin } \\
(Yudisium/Wisuda) & L & P \\
\hline 2017 & 10 & 24 \\
2018 & 28 & 55 \\
2019 & 35 & 53 \\
2020 & 20 & 25 \\
Jumlah (orang) & $\mathbf{9 3}$ & $\mathbf{1 5 7}$ \\
Jumlah (\%) & $\mathbf{3 7 \%}$ & $\mathbf{6 3 \%}$ \\
\hline
\end{tabular}

Sumber : Data Primer Diolah (2020)

Tabel 4.1 menunjukkan dari 250 responden (alumni), 93 orang berjenis kelamin laki-laki dan 157 orang berjenis kelamin perempuan, atau $37 \%$ responden adalah berkelamin laki-laki, dan $63 \%$ responden berjenis kelamin perempuan.

Lulusan (alumni) Program Studi S1 Akuntansi berdasarkan periode tahun lulus (yudisium) ditunjukkan pada tabel 4.2 berikut:

Tabel 4.2. Lulusan Prodi S1 Akuntansi Berdasarkan Periode Yudisium

\begin{tabular}{ccc}
\hline Tahun Yudisium & Jumlah & \% \\
\hline 2017 & 34 & $14 \%$ \\
2018 & 83 & $33 \%$ \\
2019 & 88 & $35 \%$ \\
2020 & 45 & $18 \%$ \\
Jumlah & $\mathbf{2 5 0}$ & $\mathbf{1 0 0}$ \\
\hline
\end{tabular}

Sumber : Data Primer Diolah (2020)

Berdasarkan Tabel 4.2 dapat dilihat responden terbanyak berasal dari angkatan wisuda tahun 2019, atau sebanyak 88 orang, dan jumlah terkecil berasal dari angkatan wisuda tahun 2017, yaitu berjumlah 34 orang, atau 14\% dari total responden, hal ini disebabkan karena proses penyebaran kuisioner terlaksana pada pertengahan tahun 2020 yaitu tepatnya pada bulan Mei hingga bulan Juni 2020. Penyebaran kuesioner menggunakan link google form (https://bit.ly/Tracer_S1_Ak) untuk alumni dan (https://bit.ly/Kuesioner_Penggunalulusan) untuk disebarkan ke pengguna lulusandengan tujuan efektivitas penjangkauan alumni dan efisiensi waktu. Selain itu juga kondisi saat itu juga sangat mengharuskan penyebaran kuesioner menggunakan google form mengingat masa pandemi Covid 19, dimana adanya edaran pemerintah untuk menghindarai kerumunan dan tidak keluar rumah jika tidak terlalu penting guna menghambat penyebaran wabah covid-19. Hal tersebut menjadi salah satu penyebab kurangnya minat alumni mengisi kuesioner, dikarenakan banyaknya perusahaan yang mulai merumahkan karyawannya, sedangkan bagi lulusan fresh graduate yaitu lulusan 2019 dan 2020 tentu juga memiliki kesempatan yang sangat minim untuk bisa masuk ke duani kerja. Dan ini menjadi salah satu yang membuat alumni kurang bersemangat untuk mengisi kuesioner karena sebagian berfikir bahwa tidak ada yang bisa diisi dikarenakan alumni rata-rata belum mendapatkan pekerjaan, bahkan yang sudah bekerjapun banyak yang dirumahkan sementara. Kondisi ini terjadi secara mendunia yang diakibatkan oleh pandemi covid-19. 


\section{Analisis Data}

Penelitian ini adalah penelitian deskriptif sedangkan analisisnya menggunakan tabulasi dengan memberikan penjelasan atas tabulasi tersebut dan rekomendasi terkait dengan variabel yang digunakan. Adapun variabel yang akan dianalisis adalah output dan outcomes karena 2 variabel tersebut adalah pengukur keberhasilan lembaga pendidikan dalam memenuhi kebutuan stakeholder. Output diukur dengan Indeks Prestasi Komulatif (IPK), masa studi, Lama Waktu Tunggu Memperoleh Pekerjaan Pertama dan Besaran Gaji. Outcomes diukur dengan jumlah peminat Prodi S1 akuntansi dan pengguna lulusan akuntansi.

\section{Input (Jenis Beasiswa Yang PernahDidapatkanLulusan di Prodi S1Akuntansi)}

Pada Program Studi S1 Akuntansi rutin membuka dua (2) jenis beasiswa setiap tahunnya. Yaitu Beasiswa jalur prestasi yang diistilahkan dengan beasiswa PPA dan beasiswa untuk mahasiswa kurang mampu yang sering diistilahkan dengan beasiswa BBM. Namun demikian beberapa mahasiswa yang lulus seleksi masuk Prodi S1 juga mendapatkan beasiswa yang diadakan dari Pemerintah Pusat seperti Beasiswa Adik; Beasiswa Bidik misi; Beasiswa Afirmasi. Berikuta dalah data mahasiswa yang yang mendapatkan beasiswa, baik dari program pemerintah Pusat maupun dari Prodi S1 Akuntansi sendiri:

Tabel 4.3.ProsentasePenerimaBeasiswaTahun 2017 - 2020

\begin{tabular}{llcc}
\hline No & Jenis Beasiswa & Jumlah & Prosentase \\
\hline 1 & Beasiswa Adik & 01 orang & $1 \%$ \\
2 & Beasiswa Bidikmisi & 05 orang & $6 \%$ \\
3 & Beasiswa PPA & 11 orang & $7 \%$ \\
4 & Beasiswa Afirmasi & 01 orang & $1 \%$ \\
5 & Tidak mendapatkan beasiswa & 232orang & $85 \%$ \\
& Jumlah & 250orang & $100 \%$ \\
\hline
\end{tabular}

Sumber : Data Primer Diolah (2020)

\section{Output}

\section{Indeks Prestasi Kumulatif (IPK)}

Indeks Prestasi Komulatif (IPK) merupakan ukuran keberhasilan (nilai) mahasiswa yang dihitung mulai sejak menempuh studi pertama kali sampai semester terakhir yang diakhiri dengan PKL dan Ujian Laporan PKL. IPK tertinggi adalah 4 dengan skala 0 - 4. Semakin tinggi IPK mahasiswa maka tingkat keberhasilan untuk menerima materi yang disampaikan Dosen semakin tinggi dan sebaliknya. IPK alumni Program Studi S1 akuntansi periode wisuda 2017 2020 dapat dilihat pada tabel 4.3 berikut:

Tabel 4.4. IPK Alumni Program Studi S1 Akuntansi Periode Wisuda 2017 - 2020

\begin{tabular}{ccc}
\hline No. & $\begin{array}{c}\text { Tahun } \\
\text { (Yudisium/Wisuda) }\end{array}$ & IPK (Rata-Rata) \\
\hline 2 & 2017 & 3,22 \\
3 & 2018 & 3,22 \\
4 & 2019 & 3,17 \\
5 & 2020 & 3,22 \\
& Rata-Rata & $\mathbf{3 , 2 1}$ \\
\hline
\end{tabular}

Sumber : Data Primer Diolah (2020) 
Berdasarkan hasil pada tabel 4.4 dapat dilihat bahwa IPK tertinggi diperoleh mahasiswa yang yudisium (wisuda) pada tahun 2017, 2018 dan 2020dengan IPK rata-rata 3,22 dan IPK terendah pada mahasiswa yang yudisium tahun 2019 yaitu rata-rata 3,17. Secara keseluruhan IPK rata-rata alumni masih di atas 3 (sangat memuaskan) yaitu 3,21.

\section{Masa Studi}

Masa studi merupakan waktu yang diperlukan oleh mahasiswa untuk menyelesaikan studi (kuliah) yang dihitung sejak terdaftar menjadi mahasiswa sampai dengan yudisium akhir. Semakin cepat masa studi maka semakin baik. Masa studi normal untuk Prodi S1 adalah selama 4,6 Tahun (9 semester).

Masa studi alumni Prodi S1akuntansi periode wisuda 2017-2020 dapat dilihat pada tabel 4.5. berikut:

Tabel 4.5. Masa Studi Alumni Program Studi S1 Akuntansi Periode Wisuda 2016 - 2020

\begin{tabular}{ccc}
\hline No. & $\begin{array}{c}\text { Tahun } \\
\text { (Yudisium/Wisuda) }\end{array}$ & $\begin{array}{c}\text { Masa Studi } \\
\text { (bulan) }\end{array}$ \\
\hline 1 & 2017 & 4,5 th \\
2 & 2018 & 4,6 th \\
3 & 2019 & 4,7 th \\
4 & 2020 & 4,5 th \\
& Rata-Rata & $\mathbf{4 , 6}$ th \\
\hline
\end{tabular}

Sumber : Data Primer Diolah (2020)

Hasil tabel 4.5 menjelaskan bahwa masa studi paling lama adalah mahasiswa yang yudisium (wisuda) pada tahun 2019 yaitu 4,7 tahun, sedangkan masa studi paling cepat adalah mahasiswa yang yudisium tahun 2017dan 2020 yaitu 4,5 tahun. Secara keseluruhan, mahasiswa akuntansi yang wisuda periode 2017 - 20120 masa studi rata-rata adalah 4,6 Tahun.

\section{Masa Tunggu Untuk Mendapatkan Pekerjaan Utama}

Lama waktu tunggu memperoleh pekerjaan pertama merupakan merupakan waktu tunggu untuk memperoleh pekerjaaan pertama kali sejak sejak wisuda. Semakin cepat waktu tunggu untuk memperoleh pekerjaan pertama menunjukkan daya serap lulusan dimanfaatkan oleh pihak eksternal semakin bagus. Waktu tunggu alumni Program Studi S1akuntansi periode wisuda 2017 - 2020 dapat dilihat pada tabel 4.5 berikut:

Tabel 4.6. Waktu Tunggu Alumni Prodi S1 Akuntansi Periode Wisuda 2017 - 2020

\begin{tabular}{ccc}
\hline No. & $\begin{array}{c}\text { Tahun } \\
\text { (Yudisium/Wisuda) }\end{array}$ & $\begin{array}{c}\text { Waktu Tunggu } \\
\text { (Bulan) }\end{array}$ \\
\hline 1 & 2017 & 2,5 bulan \\
2 & 2018 & 4,8 bulan \\
3 & 2019 & 5,4 bulan \\
4 & 2020 & 2,2 bulan \\
& Rata-Rata & 4,0 bulan \\
\hline
\end{tabular}

Sumber : Data primer diolah (2020) 
Berdasarkan hasil pada tabel 4.5 dapat dilihat bahwa waktu tunggu paling lama untuk memperoleh pekerjaan pertama adalah mahasiswa yang yudisium (wisuda) pada tahun 2019 yaitu dengan waktu 5,4 bulan dan waktu tunggu tercepat untuk memperoleh pekerjaan pertama adalah mahasiswa yang yudisium tahun 2020 yaitu hanya 2,2bulan. Namun untuk data tahun 2020 belum bisa menggambarkan kondisi alumni secara keseluruhan, karena alumni tahun 2020 yang mengisi kuesioner sangat tidak representatif. Secara keseluruhan waktu tunggu ratarata alumni memperoleh pekerjaan pertama adalah 4 bulan.

\section{Pekerjaan Sambilan Yang Dimiliki Lulusan dan Besaran Penghasilannya}

Pekerjaan sambilan yang dimiliki lulusan maksudnya adalah adakah lulusan memiliki pekerjaan lain yang menjadi pekerjaan sampingan selain pekerjaan utama yang dimiliki oleh alumni tersebut. Dan berdasarkan data yang diperoleh, ternyata tidak sedikit alumni yang memiliki pekerjaan sampingan selain pekerjaan utamanya tersebut. Pekerjaan sampingann yaini kebanyakan bergelut di bidang jualan online. Pekerjaan ini cukup menjanjikan dan tidak mengganggu jam pekerjaan utama tentunya. Oleh karena itu tidak heran jika jualan online ini dipilih sebagai pekerjaan alternatif untuk menambah penghasilan. Berdasarkan hasil tabulasi kuisioner, teridentifikasi bahwa terdapat $90 \%$ memiliki pekerjaan sampingan, dengan besaran penghasilan bervariasi dari Rp. 500.000 - Rp. 10.000.000 bergantung besarnya usaha yang dimiliki.

\section{Besaran Gaji Yang Diperoleh Lulusan dari Pekerjaan Utama}

Besaran gaji pertama adalah besarnya gaji yang diterima saat pertama kali bekerja oleh alumni program studi S1 akuntansi. Besaran gaji pertama untuk ke 250 responden tersebut dapat dilihat pada tabel 4.7 berikut:

Tabel 4.7. Besaran Gaji Alumni Prodi S1 Akuntansi Periode Wisuda 2017 - 2020

\begin{tabular}{clc}
\hline No. & \multicolumn{1}{c}{ Gaji } & \% \\
\hline 1 & Kurang dari Rp 1.000.000 & $10 \%$ \\
2 & Rp 1.000.000 - Rp 3.000.000 & $50 \%$ \\
3 & Rp 3.000.000- Rp 5.000.000 & $29 \%$ \\
4 & Rp 5.000.000- Rp 7.500.000 & $8 \%$ \\
5 & Rp 7.500.000- Rp 10.000.000 & $0 \%$ \\
6 & Lebih dari Rp 10.000.000 & $3 \%$ \\
& Total & $100 \%$ \\
\hline
\end{tabular}

Sumber : Data Primer Diolah (2020)

Berdasarkan hasil pada tabel 4.7 dapat dilihat bahwa besarnya gaji yang diterima oleh alumni Prodi S1 Akuntansi pada waktu pertama kali bekerja setelah lulus (wisuda) sebanyak $10 \%$ memperoleh gaji di bawah Rp 1.000.000, $50 \%$ dengan penghasilan Rp 1.000 .000 - Rp 3.000.000, 29\% dengan penghasilan Rp 3.000.000 - Rp 5.000.000, dan 8\% dengan penghasilan $\mathrm{Rp}$ 5.000.000 - Rp 7.500.000. 3\% dengan penghasilan di atas 10.000.000. Hasil ini menunjukkan bahwa sebagian besar alumni mengutamakan pengalaman kerja dibandingkan dengan besaran gaji yang diterima. 


\section{Hubungan Antara Bidang Studi denganPekerjaanLulusan}

Hubungan antara bidang studi dengan pekerjaan lulusan, maksudnya adalah untuk melihat seberapa erat hubungan antara Bidang Studi dengan pekerjaan yang dijalankan oleh lulusan saat ini. Apakah sangat erat, erat, cukup erat, kurang erat atau bahkan tidak ada hubungan sama sekali? Table 4.8 berikut memberikan gambaran tentang hubungan antara bidang studi dengan pekrjaan lulusan.

Tabel 4.8. Hubungan Antara Bidang Studi denganPekerjaanLulusan 2017 - 2020

\begin{tabular}{clc}
\hline No. & \multicolumn{1}{c}{ KeteranganHubungan } & $\%$ \\
\hline 1 & Sangat Erat & $18 \%$ \\
2 & Erat & $39 \%$ \\
3 & Cukup Erat & $37 \%$ \\
4 & Kurang Erat & $3 \%$ \\
5 & Tidak Ada Hubungan & $3 \%$ \\
& Total & $100 \%$ \\
\hline
\end{tabular}

Sumber : Data Primer Diolah (2020)

Berdasarkan tabulasi data yang ada, dari 250 responden terdapat $18 \%$ lulusan memiliki pekerjaan yang sangat erat kaitannya dengan Bidang Studi Akuntansi, $39 \%$ orang memiliki pekerjaan yang erat hubungannya dengan bidang studi akuntansi, $37 \%$ lulusan memiliki pekerjaan yang cukup erat kaitannya dengan bidang studi akuntansi, 3\% orang memiliki pekerjaan yang kurang erat hubungannya dengan bidang studi akuntansi, dan $3 \%$ orang memiliki pekerjaan yang tidak ada hubungannya sama sekali dengan bidang studi akuntansi.

\section{Tingkat Pendidikan Yang Paling SesuaiDenganPekerjaanLulusan}

Pada kuisioner juga menanyakan kepadalulusan (alumni) terkait dengan tingkat pendidikan yang paling tepat/ paling sesuai untuk pekerjaan yang sedang dijalankan sekarang. Apakah jenjang pendidikan yang dibutuhkan setingkat lebih tinggi, tingkat yang sama, atau tidak perlu pendidikan tinggi? Pada table 4.9 berikut merupakan gambaran untuk tingkat pendidikan yang paling sesuai dengan pekerjaan lulusan:

Tabel 4.9. Tingkat Pendidikan Yang Paling Sesuai Dengan Pekerjaan Lulusan 2017 2020

\begin{tabular}{clc}
\hline No. & \multicolumn{1}{c}{ KeteranganHubungan } & \% \\
\hline 1 & Setingkat Lebih Tinggi & $11 \%$ \\
2 & Setingkat/Sesuai & $84 \%$ \\
3 & Tidak Butuh Pendidikan Tinggi & $5 \%$ \\
& Total & $100 \%$ \\
\hline
\end{tabular}

Sumber : Data Primer Diolah (2020) 
Dan berdasarkan hasil tabulasi jawaban responden bahwa dari250 orang responden, ada11\% orang menyatakan bahwa tingkat Pendidikan yang paling sesuai dengan pekerjaan yang dijalankan sekarang adalah setingkat lebih tinggi dari jenjang pendidikan S1, dengan kata lain untuk pekerjaan yang dijalankan sekarang ini sebenarnya dibutuhkan Pendidikan paling rendah setara Sarjana Strata -2 (S2). Hal ini juga menjelaskan bahwa sebanyak11\% lulusan S1 Akuntansi Unram bisa bersaing dengan jenjang Pendidikan yang setingkat lebih tinggi dari jenjang diploma. Sebanyak 84\% alumni menyatakan bahwa pekerjaan yang mereka jalankan sekarang ini sudah sesuai dengan jenjang pendidikannya, yaitu prodi S1 Akuntansi. Selain itu sebanyak5\% orang menyatakan bahwa pekerjaan yang dijalankan sekarang ini tidak butuh Pendidikan yang tinggi, dengan kata lain sebanyak 5\% lulusan S1 Akuntansi Unram tidak bisa menerapkan ilmu yang dimilikinya pada bidang pekerjaan yang dijalankan.

\section{Outcomes}

Kepercayaan instansi/institusi maupun masyarakat akan kualitas alumni (lulusan Program Studi S1 Akuntansi Universtias Mataram menyebabkan outcome atas lulusan itu sendiri semakin meningkat. Outcomes diukur dengan jumlah peminat Prodi S1 akuntansi dan pengguna lulusan.

\section{Jumlah Peminat Program Studi S1 Akuntansi}

Penerimaan mahasiswa masuk Universitas Mataram dilakukan melalui tiga (3) jalur yaitu jalur SNMPTN, SBMPTN dan Jalur Mandiri. Jumlah peminat Prodi S1 Akuntansi merupakan jumlah calon mahasiswa yang mendaftar di Program Studi S1 Akuntansi Fakultas Ekonomi dan Bisnis Universitas Mataram. Hasil yang diperoleh dari Rektorat Universitas Mataram menunjukkan bahwa jumlah peminat Prodi S1 akuntansi dari tiga jalur penerimaan mahasiswa baru untuk tahun dari tahun 2017sampai dengan tahun 2020 rata-rata sebanyak 5308 calon mahasiswa baru. Rata-rata sebanyak 811 orang melalui jalur Mandiri. Dari jumlah tersebut, yang diterima menjadi mahasiswa Program Studi S1 Akuntansi adalah sebanyak 57 orang, jalur SNMPTN rata-rata peminatnya sebanyak 1500 orang dan dari jalur SBMPTN rata-rata sebanyak 3000 orang.

Berdasarkan jumlah peminat yang cukup besar tersebut, Program Studi S1 Akuntansi masih cukup diminati oleh masyarakat. Tingkat keketatan persaingan cukup tinggi, yaitu rasio persaingan untuk jalur masuk SNMPTN $1: 23$ orang, jalur masuk SBMPTN 1:50 orang dan jalur mandiri $1 ; 14$ orang. Progam Studi S1 Akuntansi bisa bersaing dengan perguruan tinggi besar lainnya di Indonesia, bahkan pernah menjadi jurusan dengan tingkat peminta tertinggi di Indonesia.Walaupun pada kondisi covid-19 ini terjadi penurunan minat, namun penurunannya tidak terlalu banyak dan hal tersebut juga bisa dimaklumi dikarenakan daya beli masyarakat yang sangat menurun. Dimana masyarakan berada pada posisi bertahan untuk hidup, sehingga tabungan yang ada beralih fungsi, yang tadinya bisa jadi rencana akan diperuntukkan untuk biaya pendidikan, namun harus direlakan untuk memenuhi keutuhan sehari-hari dikarenakan pertumbuhan ekonomi yang terus melambat bahkan mengalami resesi.

\section{Jenis Perusahaan/InstansiTempatLulusanBekerja(Pengguna Lulusan)}

Pengguna lulusan merupakan instansi (institusi) yang menggunakan lulusan Program Studi S1 Akuntansi Fakultas Ekonomi Universitas Mataram sebagai pegawai (karyawan). Hasil kuisioner tentang pengguna lulusan dapat dilihat pada tabel 4.9 berikut ini: 
Tabel 4.10. Pengguna Lulusan Program Studi S1 Akuntansi Periode Wisuda 2017 2020

\begin{tabular}{clc}
\hline No. & \multicolumn{1}{c}{ Jenis Instansi/Usaha } & \% \\
\hline 1 & Instansi Pemerintah & $22 \%$ \\
2 & Organisasi Non-Profit & $2 \%$ \\
3 & Perusahaan Swasta & $54 \%$ \\
4 & Wiraswasta & $10 \%$ \\
5 & Lainnya & $12 \%$ \\
& Total & $100 \%$ \\
\hline
\end{tabular}

Sumber : Data Primer Diolah (2020)

Berdasarkan Tabel 4.10, dapat dilihat bahwa alumni Program Studi S1 Akuntansi terbanyak bekerja pada Perusahaan Swasta Jasa, yaitu sebanyak 54\%, sebanyak 22\% bekerja pada Instansi Pemerintah, $2 \%$ bekerja pada Organisasi Non-Profit atau Lembaga Swadaya Masyarakat, $10 \%$ bekerja sebagai wiraswasta, dan sebanyak $12 \%$ bekerja pada bidang lainnya.

Dilihat dari skala perusahaan, maka tabel 4.10 berikut merupakan gambaran skala perusahaan tempat alumni S1 Akuntansi FEB Unram bekerja:

Tabel 4.11.Skala Perusahaan Tempat Lulusan Bekerja Periode Wisuda 2017 - 2020

\begin{tabular}{clc}
\hline No. & \multicolumn{1}{c}{ Jenis Instansi/Usaha } & \% \\
\hline 1 & Lokal & $47 \%$ \\
2 & Nasional & $33 \%$ \\
3 & Internasional & $20 \%$ \\
& Total & $100 \%$
\end{tabular}

Sumber : Data Primer Diolah (2020)

Jenis instansi/perusahaan tempat para alumni bekerja adalah seperti Perbankan, Instansi Pusat seperti Universitas Mataram, Badan Pertanahan Negara, Kepolisian, dan Perusahaan Financing, dan berbagai perusahaan swasta bonafid lainnya. Banyaknya instansi (institusi) yang menggunakan alumni Prodi S1 Akuntansi Unram menunjukkan bahwa alumni Prodi S1 Akuntansi Unram masih bisa bersaing dengan prodi lainnya dalam hal perekrutan karyawan di tempat-tempat yang bonafid yang ada di Nusa Tenggara Barat (NTB).

\section{Penilaian Stakeholder}

Stakeholder adalah lembaga atau institusi yang menggunakan alumni Program Studi S1akuntansi sebagai karyawan. Dalam rangka menyesuaikan antara kebutuhan stakeholder dengan lulusan, maka program studi/jurusan harus memperbaiki kualitas dengan mengembangkan kurikulum berbasis kompetensi berdasarkan kebutuhan stakeholder.

Untuk menentukan nilai kriteria dan kategori dalam penilaian stakeholder ini dilakukan penilaian dengan menggunakan interval kelas dengan rumus sebagai berikut: 


$$
\text { Interval Kelas }=\frac{\text { Nilaitertinggi-nilaiterendah }}{\text { JumlahKelas }}
$$

Nilai skor tertinggi dalam penelitian ini adalah 4 dan nilai terendah adalah 1 yang berasal dari skala penilaian kuesioner, dan jumlah kelas adalah 4. Dengan demikian didapatkan : Interval Kelas $=\frac{4-1}{4}=0,75$

Rentang kriteria dan kategori sebagai panduan pengelompokan hasil penilaian dapat dilihat pada Tabel 4.9 berikut ini:

\section{Tabel 4.12. Rentang Kriteria dan Kategori Sebagai Panduan Pengelompokan Hasil Penilaian}

\begin{tabular}{ccc}
\hline No & Interval Kriteria & Kinerja \\
\hline 1 & $3,25 \mathrm{~s} / \mathrm{d} 4$ & Sangat Baik \\
2 & $2.50 \mathrm{~s} / \mathrm{d}<3.25$ & Baik \\
3 & $1.75 \mathrm{~s} / \mathrm{d}<2.50$ & Cukup Baik \\
4 & $1 \mathrm{~s} / \mathrm{d}<1.75$ & Kurang Baik \\
\hline
\end{tabular}
Akuntansi:

Berikut ini adalah hasil penilaian kinerja dan kualitas alumni Program Studi S1

Tabel 4.13. Penilaian Kinerja Lulusan Program Studi S1 Akuntansi Periode Wisuda 2016 - 2020

\begin{tabular}{clcc}
\hline No & & Kriteria/Aspek & Nilai \\
Rata-rata & Kinerja \\
\hline 1 & Etika & 3,46 & Sangat Baik \\
2 & Keahlian Pada Bidang Ilmu & 3.46 & Sangat Baik \\
3 & Kemampuan Berbahasa Asing & 3,15 & Baik \\
4 & Penggunaan Teknologi Informasi & 3.31 & Sangat baik \\
5 & Kemampuan Berkomunikasi & 3.38 & Sangat Baik \\
6 & Kerjasama Tim & 3.38 & Sangat Baik \\
7 & Pengembangan Diri/Kreativitas & 3.38 & Sangat Baik \\
\hline
\end{tabular}

Sumber : Data Primer Diolah (2020)

Berdasarkan Tabel 4.13, stakeholder menilai alumni Prodi S1 Akuntansi berkinerja sangat baik. Untuk kriteria etika, penggunaan Teknologi, Kemampuan berkomunikasi ,dan kerjasama tim alumni dinilai sangat baik oleh para stakeholder. Yang perlu mendapatkan perhatian adalah pada kriteria kemampuan untuk berbahasa asing yang bernilai paling rendah, pada penilaian juga mendapatkan penilaian yang agak rendah dengan nilai rata-rata 3,15 dengan kriteria baik. Pada pertanyaan berbeda, secara keseluruhan, tingkat kepuasan stakeholder terhadap alumni Prodi S1 akuntansi menunjukkan bahwa stakeholder merasasangatpuas. Alumni Prodi S1 Akuntansi mempunyai tempat bagi stakeholder untuk dijadikan sebagai karyawan/pegawai di tempat mereka.Selain itu juga, stakeholder memberikan respon positif terhadap alumni Prodi S1 akuntansi. Hal ini terbukti dengan adamya permintaan alumni Prodi S1 akuntansi sebagai karyawan/pegawai di instansi mereka.

Tujuan dari tracer study ini sebenarnya untuk menyeimbangkan kurikulum yang ada di Prodi S1akuntansi Universitas Mataram dengan kebutuhan pengguna (stakeholder). Kurikulum 
yang semakin mendekati kebutuhan stakeholder akan semakin baik dan ini membuktikan bahwa kurikulum tersebut sudah efektif. Salah satu cara untuk menggali hal tersebut adalah dengan menerima masukan dan saran dari stakeholder. Adapun saran dari stakeholder adalah

1. Alumni Prodi S1 Akuntansi tetap mengikuti permintaan di pasar kerja.

2. Supaya ke depannya mampu melaksanakan penidikan karakter berbasis mental dan keprilakuan serta mampu mendorong sikap pengembangan diri yang berkelanjutan.

3. Sebaikanya program KKN Untuk Mahasiswa FEB Unram diganti Dengan KKI (Kuliah kerja Industri), agar Mahasiswa dapat meningkatkan kompetensinya dan dapat bersesuain dnegan kebutuhan Industri

4. Diupayakan untuk penguasaan semua laporan keuangan berbagai bidang usaha, jangan hanya bisnis jasa dan manufaktur.

5. Harus lebih baik dari agkatan sebelumnya,tidak manja dan harus punya inisiatif dalam kerjasama dengan team.

6. Semoga bisa menciptkan lulusan lulusan terbaik yg tahan kerasnya dunia kerja.

7. Skill dan konsep akuntansi ditingkatkan.

8. Lebih banyak mengexplor kemampuan bhs ingris spy cepet beradaptasi dengan dunia kerja baik usaha asing maupun domistik.

Dalam pengelolaan Program Studi dan proses pembelajaran, stakeholder juga menyarankan agar adanya peningkatan sarana dan prasarana perkuliahan yang bisa menciptakan suasana yang kondusif bagi mahasiswa untuk mengikuti pembelajaran di kampus. Di samping itu, Program Studi juga dituntut untuk terus mengembangkan kerjasama dengan berbagai instansi dan perusahaan swasta, dalam penempatan magang, dan juga kerjasama untuk mempermudah penyerapan alumni Program Studi S1 Akuntansi di dunia kerja.

Saran-saran yang diberikan oleh stakeholder sudah ditindaklanjuti oleh Program Studi S1 Akuntansi, dengan melakukan rekonstruksi kurikulum, penyusunan Rencana Perkuliahan Semester dan Rencana Tugas Mandiri yang disesuaikan dengan profil lulusan yang disesuaikan dengan keinginan stakeholder. Khusus untuk mata kuliah bahasa Inggris umum maupun special purpose untukekonomi dan bisnis serta komputer akuntansi dengan excel akuntansi maupun software akuntansi yang lainnya harus ditingkatkan dalam praktik

Untuk mata kuliah tertentu akan diberikan porsi praktik (latihan) maupun kasus yang lebih banyak seperti Pengantar Akuntansi dan Akuntansi Keuangan, Auditing dan Akuntansi untuk Koperasi dan UMKM, Akuntansi Perbankan Konvensional, Akuntansi Sektor Publik. Hal yang sangat perlu diperhatikan oleh Prodi S1 Akuntansi adalah peningkatan soft skill antara lain kemampuan bekerjasama, kemampuan berkomunikasi, jujur dan disiplin. Peningkatan soft skill ini biasanya ada pada mata kuliah seminar dan mata kuliah perilaku organisasi yang menekankan kemampuan berkomunikasi. Kejujuran dan disiplin itu ditekankan pada mata kuliah Agama dan semua mata kuliah.

Peningkatan sarana dan prasarana harus ditingkatkan, seperti dengan adanya pengadaan komputer yang memadai secara spesifikasi untuk praktik, ruang kelas yang nyaman dan sebagainya. Kerjasama dengan berbagai pihak, juga harus terus ditingkatkan, dengan mengintensifkan program praktik kerja lapangan dan meningkatkan kerjasama yang telah dibina selama ini, untuk memudahkan penyaluran alumni sebagai tenaga kerja pada perusahaan/instansi.

\section{Interpretasi}

Relevansi atau tidaknya kurikulum suatu jurusan dapat dinilai dengan tracer study. Tracer study memberikan informasi terkait kompetensi lulusan yang sesuai dengan kebutuhan pekerjaan maupun stakeholders. Kompetensi lulusan dapat dilihat dari Indeks Prestasi 
Komulatif. Semakin tinggi IPK mahasiswa maka tingkat keberhasilan untuk menerima materi yang disampaikan Dosen semakin tinggi dan sebaliknya. Hasil penelitian menunjukkan IPK rata-rata alumni Prodi S1 Akuntansi sebesar 3,21 (sangat memuaskan), jika dilihat dari IPK minimum untuk memperoleh pekerjaan terutama PNS sudah memenuhi syarat. Hal ini menunjukkan bahwa lulusan Prodi S1 Akuntansi layak untuk dijadikan pegawai/karyawan di instansi swasta maupun negeri karena dari segi pemahaman materi sudah baik.

Masa studi menurut hasil penelitian menunjukkan masa studi rata-rata adalah 4,6Tahun. Hasil ini memberikan informasi bahwa masa studi lulusan masih baik, karena ku---ng dari 5 Tahun sebagai masa pendidikan normal. Dilihat dari masa tunggu untuk memperoleh pekerjaan pertama sekitar 4,0 bulan dengan gaji paling banyak berkisar pada Rp 1.000 .000 - Rp 3.000.000. Hasil ini menunjukkan bahwa sebagian besar alumni Prodi S1 akuntansi lebih mengutamakan pengalaman kerja dibandingkan dengan gaji.

\section{SIMPULAN}

Berdasarkan hasil pembahasan pada bab 4 dapat ditarik beberapa simpulan bahwa kinerja alumni Prodi S1 akuntansi menurut stakeholders adalah sangat baik. Masa tunggu alumni sampai mendapatkan pekerjaan pertamanya adalah 4 bulan. Namun angka ini belum bisa menggambarkan kondisi sebenarnya terutama untuk angkatan tahun 2020, dimana angkatan tahun 2020 yang memiliki masa tunggu yang paling cepat, sementara tahun 2020 ini adalah masa-masa dilakukan PHK besar-besaran oleh berbagai perusahaan, sehingga kesempatan bagi fresh graduate untuk bergabung ke dunia kerja sangat tipis, namun demikian ada bebarapa yang ternyata mendapatkan kesempatan bergabung ke dunia kerja, dan tentu angkanya masih sedikit dan angka ini jugalah yang masuk sebagai pengisi kuesioner, sehingga data alumni tahun 2020 belum representatif untuk menggambarkan keadaan alumni tahun 2020 secara keseluruhan. Relevansi antara kurikulum dengan kebutuhan stakeholder sudah cukup sesuai, yang bisa dilihat dengan layaknya lulusan Program Studi S1 Akuntansi untuk bekerja pada berbagai organisasi, baik swasta maupun pemerintahan. Selain itu, beberapa hal yang perlu rekonstruksi terhadap kurikulum yang bisa meningkatkan peningkatan kemampuan lulusan terutama terkait dengan bahasa inggris, komputer akuntansi, soft skill dan kemampuan pendukung lainnya.

Selama penelitian ini, hanya sedikit responden dalam tracer study ini yang mengisi kuesioner sehingga tidak mencerminkan keadaaan alumni yang sebenarnya dan pada akhirnya tidak bisa digeneralisasi. Di samping itu, keterbatasan waktu untuk menunggu pengisian kuisioner yang telah disebar kepada para responden. Terutama pada tahun 2020 ini, penyebaran kuesioner terhambat dengan adanya kodisi pandemi covid-19. Sehingga penyebaran kuesioner menggunakan media google form, namun demikian semangat alumni untuk mengisi kuesioner tidak begitu besar, terbukti dari jumlah mahasiswa yang mengisi kuesioner yang sangat sedikit dibandingkan dengan jumlah alumni. Penyebaran link kuesioner menggunakan media WA grup alumni. Penulis mencoba untuk menggali alasan alumni yang tidak mengisi kuesioner melalui chat WA, dan jawaban yang diperoleh rata-rata menyatakan bahwa alumni belum mendapatkan pekerjaan.

Keterbatasan yang dialami selama penelitian dapat dijadikan masukan untuk tracer study berikutnya. Tracer study berikutnya, kuesioner lebih banyak disebarkan ke semua wilayah di Propinsi Nusa Tenggara Barat bahkan kalau perlu ke luar daerah dimana alumni tersebut bekerja dan memanfaatkan sosial media serta email sebagai sarana penyebaran kuesioner. Selain itu, perlu diambil strategi yang efektif dalam penyebaran link google form, seperti fokuskan bahwa kuesioner menggunakan link google form, dan konpensasi pengisian 
kuesioner fokus pada pengisian google form, tidak menggunakan kuesioner manual seperti sebelumnya. Sehingga biaya penggandaan instrumen tracer bisa dialihkan ke pemberian konpensasi ke responden yang mengisi kuesioner tracer

\section{DAFTAR PUSTAKA}

Anonim. 2000. KeputusanMenteri Pendidikan Nasional Republik IndonesiaNomor 232/U/2000TentangPedoman Penyusunan Kurikulum Pendidikan TinggiDan Penilaian Hasil Belajar MahasiswaMenteri Pendidikan Nasional.

.2005. Peraturan Pemerintah Republik Indonesia Nomor 19 Tahun 2005 Tentang Standar Nasional Pendidikan

.2010. PeraturanPemerintah No.17 Tahun 2010 tentang pengelolaan dan penyelenggaraan pendidikan

2011. Manual Prosedur Tracer Study Fakultas Pertanian Universitas Brawijaya Malang.https://www.google.com/url?sa=f\&rct=j\&url=http://gjm.fp.ub.ac.id/documents/ doc/tracer_study.pdf\&q=\&esrc=s\&ei=HeGNUYLNFMPprQfAmYDgCQ\&usg=AFQjC NGJmzYdAqp3U6eMplLgJi9KypXPaw. Diunduh tanggal 11 Mei 2013. , 2012. Buku Pedoman Akademik Fakultas Ekonomi Universitas Mataram.

Budi, Bambang, Setia. Hanson, Endra, Kusuma. Odah. 2012. Report 2012. Tracer Study dan Kepuasan Pengguna. ITB Career Center Lembaga Kemahasiswaan. karir.itb.ac.id. diunduh tanggal 11 Mei 2013

Cahyaningtyas, Susi Retna. Ali, Fikri. Siti, Atikah. Wahidatul, Husnaini. Lukman, Effendy. 2012. Analisis Keberagaman Karya Tulis Ilmiah dan Masa Studi sebagai Cermin Proses Pendidikan Pada Jurusan Akuntansi. Laporan Penelitian Dana BOPTN Universitas Mataram.

Cahyaningtyas, Susi. Retna Siti, Atikah. Wahidatul, Husnaini. 2008. Pengembangan Kurikulum Akuntansi (Strata satu) ke Arah Dunia Kerja Pada Program Studi Akuntansi FakultasEkonomi Universitas Mataram. Laporan Penelitian Dosen Muda Dikti.

Cahyaningtyas, Susi Retna. 2007. Penerapan Kurikulum Berbasis Kompetensi Pada Kurikulum Program Studi Akuntansi Stratasatu (S1) Dalam Rangka Meningkatkan Mutu Pendidikan Perguruan Tinggi (Studi Kasus Pada Universitas Gadjah Mada, Universitas Surabaya, dan STIE PERBANAS Surabaya). Thesis. Unpublished. Pascasarjana Universitas Airlangga, Surabaya.

Dikti. 2012. panduanpengembangan dan penyusunanKurikulum Pendidikan Tinggi (KPT) PendekatanKurikulumBerbasisKomptensi (KBK) dan Pendidikan BerbasisCapaian (PBC).

.2008. Buku Panduan Pengembangan Kurikulum Berbasis Kompetensi Pendidikan Tinggi

Mukhtaruddin, Andriani. 1999. Persepsi Mahasiswa Akuntansi Di Palembang Terhadap Rekayasa Kurikulum Akuntansi 1991. Simposium Nasional Akuntansi II. Malang.

Rahmadi. 2012. Ayo Partisipasi Dalam Tracer Study UI 2012. http://cdc.ui.ac.id/index.php?option=com_content\&task=view\&id=778\&Itemid=121. Diunduh tanggal 11 Mei 2013 
Syamsudin, Amir. Muthmainnah Rina, Wulandari. 2006. LaporanPenelusuran Alumni Program Studi D-II PGTK FIP UNY .https://www.google.com/search?sclient=psy$\mathrm{ab} \& \mathrm{q}=$ proposal+tracer+study\&oq=proposal+tracer+study\&gs_l=serp.3...6614035.6619

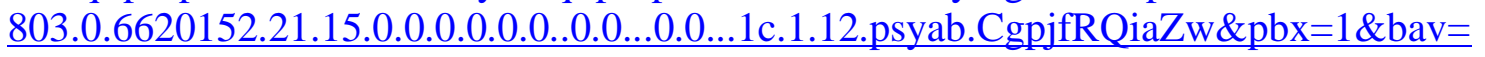
on.2,or.r_cp.r_qf.\&biw=1024\&bih=630\&ech=1\&psi=aG2MUZPNcWkrQfPo4FA.1368 $157722608.3 \&$ emsg=NCSR\&noj=1\&ei=sG2MUcDYN8PqrQfHiYDoDg. Diunduh tanggal 6 Mei 2013

Yusuf, Rusli. T.M. Iqbalsyah. Asep, Rusyana. Taufik, F. Abidin. Syaiful, Bahri. Rika, Marlia. Irvanizam. Sayed, Muchallil. Emi, Nurmasyitah. 2012. Tracer Study Unsyiah 2012 Transisi Dari Dunia Kampus ke Dunia Kerja. Universitas Syiah Kuala 